\title{
TOWARDS QUANTUM ECONOMIC DEVELOPMENT: TRANSCENDING BOUNDARIES
}

\author{
Yrd. Doç. Dr. Murat Ali Dulupçu - Murat Okçu \\ Süleyman Demirel Üniversitesi \\ Iktisadi ve Idari Bilimler Fakültesi
}

\section{Kuantum Ekonomik Kalkınmaya Doğru: Sinırlan Aşmak Özet}

Kalkınma iktisadı ekonomi biliminin diğer alanlan gibi "fiziğe imrenme" üzerine inşa edilmiştir. Bundan dolayı kalkınma iktisadı ekonomik olguları açıkladı̆̆ını varsaysa bile asında yaptığı bu olguları inşa ve dizayn etmektir. Hem ortodoks hem de heterodoks kalkınma yaklaşımları, modernist (Newtoncu) metodolojik ve metaforik tuzak ve hileleri içermektedir.

Ironik olansa, ciddi kısıtlliklar, tutarsızlıklar ve yanlş̧ kavramsallaştırmalar bulaşmış olsa bile kalkınma iktisadının modernitenin kendisi tarafından da artık kullanılmamasıdır. Yalnızca iktisadın değişik branşlarının değil, fakat aym zamanda toplum bilimlerinin farkh alanlarının kavşak noktasında konumlanan kalkınma iktisadı bu doğasıyla, içerisinde ortodoks ve heterodoks yaklaşımları beraberce yaşatmayan (yaşatamayan) modernist proje tarafından görmezden gelinmiştir. Bu nokta çok farklı bir anlayışa -"kuantum sıçramasına"- bir şans tanımaktadır.

Bu çalışma, potansiyel olarak pek çok ima, anlam ve metafora sahip kuantum kuramının ("yeni bilimlerin") gözüyle kalkınma iktisadına yaklaşmayı denemektedir.

\section{Abstract}

Development economics has been built on "physics envy" as in other fields of economics. That's why, although development economics presumes to explain economic phenomena, in fact it is constructive, and designs them. Both orthodox and heterodox developmental approaches, consist of modernist (Newtonian) methodological and metaphorical tricks and traps.

Ironically, although infected by several serious shortcomings, inconsistencies and misconceptualisations, development economics is no longer employed by modernity itself. Development economics which stands at the crossroads of not only various given branches of economics, but also different fields of social sciences, with this very nature, has been neglected by modernist projects in which orthodox and heterodox approaches do (and could) not live together. This point gives a chance to a very different understanding, to a "quantum leap".

This paper tries to approach development economics through the lenses of quantum theory (new sciences) which potentially has many implications and metaphors. 


\section{Towards Quantum Economic Development: Transcending Boundaries}

\section{Introduction}

Until the beginning of 1980's, development economics has been popular theme or an attractive area for economists as well as for the other social scientists -sociologist, political scientists- although it has fluctuations like any other sub-fields of economics. Within a period of 40 years, when the alive or active times of discipline between Second World War and rise of neo-liberalism, development economists tried to formulate means and ways of development, explain the causes of underdevelopment, classify countries according to their development levels and construct economies depending on ideological bias, that is orthodox and heterodox theories. However, after 1980's, the interest field of economists explicitly shifted from developmental issues to the globalization and related concepts, leaving the problem of development unresolved. Interestingly, Hirschman, the leading name and the founder of development economics, manifested the decline of development economics.

Of course, the main motivation behind the neglect of development economics by modern science (economics) was not only the rise of global issues, but also the "either-or". assumption of this science based on Newtonian worldview which is not able to accept (or does not have capacity to accept) competing alternatives simultaneously. By contrast, development economics has been capturing a wider range where both orthodox and heterodox theories can live together, difficult to see at the other fields of economics. The result, ultimately, was the rejection of development economics by modernism structured by Newtonian worldview.

Interestingly, although both orthodox and heterodox development theories had fed from the same source of thought -modernism-, this characteristic is hidden at their different theoretical approaches. Orthodox development theories view economies as functioning within the limits of liberalism, and presume mainly price mechanisms as a tool that inevitably 
makes foreign (external) assistance necessary. On the other hand, heterodox development theories view economies as functioning mainly for the interest of capitalist powers and emphasis on the mal-functions of price mechanism, and presume either to leave out relations with leading capitalist countries or to see alternative models of development as a mixture of not only heterodox but also mainstream theories.

However, these seemingly different and competing theories of development, in fact, used the same basic scientific assumptions. The ghost of Newtonian science and worldview can be seen, for instance, at the different assumptions of both theories such as linearity and determinism in Rostow's orthodox stages of economic development and Marx's heterodox historical development of socialism.

These two seemingly different theories, in fact, approach to development problem with the same Newtonian assumptions. So, since the worldview is the same, the result is the same inevitably -unsuccessfulness. But the unsuccessfulness of the competing theories like Rostowian and Marxian versions does not merely arise from the lack of theoretical framework or from the analytical tools that they use. The problem is also with the phenomena itself which these orthodox and heterodox theories try to explain or construct/design. Today, we can understand this more clearly.

We, as scientists -not only economists but also scientists from the other fields of both social and physical sciences- are trained within the limits of modern science caused us to examine universe as a determinable object. Thus, economists are infected by a general well-known virus of "physics envy" aiming to obtain command-and-control on socio-economic phenomenon which is, as a matter of fact, a noncontrolable interrelated whole.

With the beginning of $20^{\text {th }}$ century and the change in the science itself, the dominance of the notion of a Newtonian self-equilibrating mechanism which enhances command and control in physical sciences as well as in orthodox and heterodox theories of development economics are challenged by some major scientific developments (KARSTEN, 1990: 385). Firstly, the publication of an article in 1905 by Albert Einstein set the stage for the beginning of "the theory of relativity" which formally proposed in 1915. Secondly, the development of quantum theory by Heisenberg, Planck, Bohr and other physicists known as students of Copenhagen School, although not fully accepted by Einstein, forces not only physicists but also social scientists to adopt a much more subtle, holistic and organic view of the nature and the universe (CAPRA, 1983). Thirdly, chaos theory developed by Edward Lorentz, questioning the linearity of modernism, supports us to heal our worldview contaminated by linearity. Additionally, fuzzy logic and autopoises are the more recent developments which must be mentioned here as the further challengers of Newtonianism. All these 
developments, named as "new sciences", tell us how we had been approaching to the universe wrongly with the Newtonian assumptions.

On the other hand, the agenda of sciences, today, is filled with a transformation. As many other social science discipline, economics is abundant with several theoretical/practical attempts to change. But we can label this transformation as "pseudo", if it does not recognize the radical change in the modern science itself. Economics should replace its Newtonian framework with quantum understanding and a "true transformation" so that the unsuccessfulness of development economics can be eliminated with wholly new reanimation /revitalization.

This paper argues that there is a fundamental difference between Newtonian and quantum-based economic development. Unfortunately, theoreticians interested in going beyond deterministic (or equilibrium) economics may not be aware of quantum's challenge and they fail to notice the difference. Therefore, economists can confuse two kinds of transformation. For the real and robust understanding of transformation, we must look at the changing patterns of scientific reasoning. As Wheatley (1996: 10-11) aptly states "we are rediscovering that the world is alive, that we are alive. This world welcomes back our most human qualities, our creativity and passion and sprit. As we leave behind the machine images, we recover a world that is supportive of us in the full expression of our humanity. The world supports our efforts to organize, to accomplish, to find meaning, more than we could have thought."

In the first section, we will argue the effects of Newtonianism in development economics referring to some basic concepts, methods and metaphors of Newtonian worldview and its intimations in both orthodox and hetorodox development theories. In the second section, the past and current status of development economics will be discussed through the lenses of "pseudo transformation". In the third section, we will try to explain quantum theory and its implications on development economics. The last section concludes.

\section{Newtonianism in Development Economics}

\subsection{The Basic Concepts and The Philosophy of Newtonianism}

Generally speaking, the Newtonian based modernism depends upon knowing and doing so that human being could get command and control on nature and society. Every object is viewed as a mechanical phenomena. The result of this is just engineering of socio-economic and natural phenomena in order to act or control. Both society and nature viewed as if they are "dead bodies" which could be modeled or leaded. 
In Newtonian physics, which has served as a constructive base for all sciences in modernism project, the past and the future of an object, even the whole universe, can be specified with exact values, that is, if we knew the present state of a system with sufficient accuracy, we could determine its complete history and its complete future (MCDANIEL/WALLS, 1997: 363-367; ÇAKIR, 1998). This determination was mainly result of "the law of gravity" and "the laws of motion" which have used for explaining causality in universe: On the one hand, the laws of motion have helped the scientists to proclaim that nature is governed and constituted by a complete causality, on the other hand the law of gravity has been used for the same purpose to explain the motions of cosmic bodies (DULUPÇU/OKÇU, 2000: 2).

At the part of social scientists, the result of simplicity and hegemony of Newtonian physics was the belief that in order to be scientific they must link their methods to physics. Thus, physics along with crucial ontological and epistemological novelties has supplied a world view not only for physicists but also for social scientists. The basic concepts of Newtonian worldview shared both by economists (social scientists) and physicists are listed in Table 1.

\section{Table 1: Basic Concepts of Newtonian Worlduiew}

\begin{tabular}{|cc|}
\hline Determinacy & Causality \\
Predictability & Bivalency \\
Divisibility & Atomism \\
Rationality & Linearrity \\
The notion of "either-or" & Proportionality \\
Order & Stability \\
Reliability and Validity & Patterrning \\
Objectivity and Impartiality & Classification / Categorizing \\
Testability & Simplicity \\
Consistency & Manageability \\
Independence & Exclusivity \\
Entativity & Reductionism \\
\hline
\end{tabular}

The basic concepts given in Table 1 helped the creation of "great machine image" at thinking base for all sciences. No other image was more suitable than the machine image for modeling the natural and social phenomena than the machine image. It is programmable, controlable, engineerable. More importantly deterministic causality behind the machine image as well represented by working clock proves the existence of a rationality in the universe. If it is necessary, mechanistic imagery makes available shredding the 
world into pieces and then reconstructing it (WHEATLEY/ KELLNER ROGERS, 1996: 10). Seeing the whole world as a great machine has been used to describe unchangeable and deterministic aspects of natural and social life. Like material world, social objects would not change their existing structure unless a force is exerted upon them (CAKIR, 1998). The effects of these concepts of physics have been in modern science that the world itself is viewed as static "dead body", incapable of creating anything for itself. Some other implications can be enumerated as follows:

- Scientists most important task became to engineer the world into existence,

- Scientists spent most of their time on constructing models according to machine logic,

- Focus was on how best to analyze, assemble, and carefully control the world,

- The ignorance of living systems because of machine world imagery,

- Isolation for engineering,

- Decomposing of the world into independently existing smallest units, that is, breaking the system into its constituent parts.

- Creating world as well-oiled machines designed by bright engineers. Any failure of this design can be resolved by simply looking for another design to impose,

- Seek to control for what we fear,

- The rise of scientists' bias toward linear associations,

- The belief of that by using appropriate quantitative tools science can know the nature of things and their relations precisely and in their entirety,

- Placing knowledge in binary categories (e.g. developed-developing, either-or) depending on the principle of bivalency that is everything and every event has clear-cut boundaries, in other words, reality is made up of discrete categories,

- Over generalization, and depending on it simplification by quantification,

- Closeness which creates artificial boundaries, instead natural ones,

- And older thoughts and attitudes are preserved for the sake of continuity of Newtonianism, that is orthodoxy.

Physics functioning as a metaphorical base, affected economics as well parallel to the developments within the discipline. For example, classical economist used the framework of Newtonian physics, neoclassical, instead, preferred to study with thermo-dynamics of their time. But both of them do not shifted from the worldview of Newton. They approached to every dimension of socio-economic reality in a mechanical manner. Economy, in mechanistic thought, operates like a machine. The parts of the machine (economy) assumed 
to be homogeneous. To do this, concepts of homo economicus and rational man are accepted (ÇAKIR, 1998: 16). Similarity makes controlling more easier. That's why, (inevitably) convergence assumption, by and large, terminates the differences between industrialized Western world and less developed countries. So, like universal law of gravity, LDC's can be managed with the same framework (model) of developed countries. Time, space and any other properties have no important meaning since the models are universally applicable. LDC's can be represented in an abstract mathematical form via tautological deductions as in the physics. (ÇAKIR, 1998: 15)

Economics, focusing on limited number on variables, became a science of discovering regularities and similarities which are observed in human behavior. Ignorance of "friction of objects" directly transferred into economics. A change in demand or supply naturally equilibrates without any friction, there is no need for intervention. Deduced natural laws served economics to copy physical laws.

Development economics, as a branch of social sciences, has infected by Newtonianism and it employed not only methodological approaches and tools developed by physics but also world view. This caused reductionism and isolatism which for a long time avoided us to see the picture as a whole.

\subsection{Some Newtonian Aspects of Development Economics}

Questions concerning the origin of both orthodox and heterodox theories of development are yet least satisfactorily resolved. From the standpoint of economic methodology this disagreement has basically focused on a perspective : Whether the theories were revolutionary or evolutionary, that is, whether development economics is characterized as an accumulation of essential features in the decades prior to the Second World War or as a sudden revolution of knowledge. In fact, this perspective can be evaluated or regarded in the "paradigm versus scientific research programs" discussion. In orthodox scientific product line consisting of Harrod-Domar, Solow, Swan, recently Lucas types of growth and Rodan, Nurkse, Lewis or Rostow types of development models, it is difficult to find a scientific revolution or even a paradigmatic shift. Same is valid for heterodox line. There are not any explicit paradigmatic differences between Marxist theories and neo-Marxist, dependency, structuralist or any other versions of heterodox theories.

Above mentioned discussion regarding whether the development economics develops in a revolutionary or an evolutionary manner can be extended by contributions of a different perspective. This perspective is that whether the development theory arise from the developments internal or external to the discipline of political economy. Philip Mirowski (1988, 1989, 1993), a famous defender of externalist approach, argues that neoclassical theory 
was formulated by a wholesale metaphorical appropriation of the analytical base of mid-nineteenth century physics. That's why, neoclassical theory cannot be regarded as a discovery, but "as an imposition on social reality of a paradigm taken from an outside field of knowledge" (CARLSON, 1997: 741-742). But, according to perspective developed in this article, we argue that Mirowski shows only one side of the "Janus-headed" modernist project. Blaming neoclassism for the transplantation of central principles of mid-ninetieth century physics misleaded economists and caused to rise of chorus of heterodox economists who argue the unnecessity of the nation of equilibrium in a world characterized by evolutionary change (see examples of NELSON, 1995; HODGSON, 1993; NELSON/WINTER, 1982; LOASBY, 1991; WITT, 1992; ROBINSON, 1979). But this criticism ignores other equally important principles, assumptions and bases of Newtonian worldview and merely focuses on equilibrium problem. It is possibly a trusim to say that even heterodox theories employ Newtonian-based concepts and line of thinking. Perhaps, the only difference is the explicit character of metaphorical appropriation in the orthodox theory. In fact, the very basic Newtonian concepts of linearity, causality, objectivity, determinacy and predictability can be found in both orthodox and heterodox development theories.

It is not possible, within the scope of a single section, to show all Newtonian metaphorical and methodological aspects of development economics. Certain general features and characteristics of some development studies, however, can be discussed in order to explain how these theories have been structured by mechanistic thought.

First of all, development economics utilizes "bivalency" which arises from "either-or" assumption of mechanistic thought. Grouping whole world into a binary category consisting of developed and less developed is an typical attempt to see the nature through Newtonian lenses. This attempt may be acceptable to some extent, but reducing development to per capita measures ignores cultural, historical, social and many other dimensions of life which also shape the quality of life. Egypt or Turkey, with a huge amount of cultural endowment are regarded as LDC's, because, developed society is simply assumed to be an idealized version of the Western (say, United States) economy, i.e., consumer society. Then the key to a consumer society is to increase per capita criteria. The large part of development economics has interested in growth rates as the "deus ex machina" to solve all issues. This is even the case of heterodox understandings, for example, much of the Marxist development literature argues that the superiority of socialism over capitalism comes from faster growth rates (WILBER/ JAMESON, 1992, xv).

Secondly, as mentioned before, linearity is found in development theories of Marx and Rostow. Rostow's stages (1956) represent the historical line through 
which the LDC is expected to pass. This linear conception of history is same with a different stages, in Marx's version (TEZEL, 1997: 168). Hirschman (1981) criticizes this linearity: "... the underdeveloped countries expected to perform like wind-on toys and lumber through the various stages of development single-mindedly." Also, Gerschenkron has argued that modern development was not repeated from country to country identically as Rostow suggested (INGHAM, 1995, 38). But even Gerschenkron was infected by Newtonianism when he classified European countries as "advanced", "moderately backward" and "very backward". Again, seemingly different Colin Clark by his structural change argument, in fact, linearized development with "primary", "secondary" and "tertiary" sector model.

Thirdly, World Bank, IMF, UN and similar organizations produce different types of development typologies, ranging income to region. This is the most easiest way to approach the development problem. By this way, an economy can be classified according to per capita dollars, T.V. sets etc. Kuznet's, Chenery's and Syrquin's (1973, 1975, 1988 respectively) studies fall within this "pattern" category of Newtonianism, although these studies lay on either empirical observations or econometrically determined development patterns. Even Ranis (1984) in his comparative historical analysis tried to find out similarities in development processes. All these approaches reduce development to some indicators, mostly economic ones. The statistical investigations of Adelman and Morris $(1967,1988)$ concerned to incorporate cultural, political and social factors in economic development, but this, as a matter of fact, extended the pattern approach which largely based inductive reasoning of mechanistic thought.

Fourthly, theories of growth of classical, neoclassical, Harrod-Domar and Cambridge types supported the mechanical thinking by promoting simple technical solutions. Neoclassical and Cambridge schools used cosmology of Newton-the self equilibrating mechanism. On the other hand, Harrod-Domar growth model by debating "knife-edge equilibrium" dealed with malfunctioning of clock image (economics), and tried to compensate this error by simple government intervention.

Fifthly, the last methodological infection that can be mentioned here is the deterministic nature of development economics that analyzes symptoms in a general manner and suggests simple healing methods. The variables, such as investment, saving, consumption, productivity, government intervention etc. (however, by excluding quality) assumed to be homogenous. Depending on this assumed homogeneity scholars and practitioners insist on formulating effective development ways and prospects. Thus, development models only increased the number of abilities and methods that the developing world have to learn. They suggest either "in-ward" or "out-ward" oriented economic development strategy, 
but not both of them simultaneously. If a country chooses one of them, via determinism, the path that it would be passing will be easily determined. That is, if the future is known, at least predicted, then a model of development can be chosen. But the development practice have taught us that same prospects do not show similar results in every cases. That means determinism and causality are ad hoc assumptions of modernism, not universal ones.

\subsection{Orthodox and Heterodox Approaches: Different Appearances of the same}

\section{Project}

The most striking characteristic of development economics is its constructive structure rather than explanatory one. Orthodox and heterodox theories of development, by constructing socio-economic systems, tried to gain power on natural, social and economic reality. Then, reality designed for the safe of command and control. If any economic system, capitalist or socialist, is designed once then there is no reason to expect surprise or shock or any other unexpected events. But the intra and inter-relations of developing countries and developed world are dynamic. This dynamism has more and wider meaning than evolutionary heterodox school has assumed or imagined. Quantum economic development does not contain a determinable evolution as heterodoxy has expected. Newtonian economic development concerns with the mechanical aspects of development process, ignores the organic aspects and the non-linear relations of development, and tests only the Newtonian assumptions. Therefore, without understanding the effect of Newtonian worldview on development economics and gaining a new approach it would be impossible to understand a new way of development. But, this is very hard task to realize because, as Danah Zohar (1998: 51) states, "understanding quantum world would not be easy, since we are well-educated in Newtonian manner".

The rules and the borders of doing science and scientific reasoning in modern world have been idealized in Newtonian physics. Following Newton, Enlightenment process continued to engage in extreme scientism the belief that science can explain, coordinate and resolve every issue of life. Different philosophical studies and additional contributions of the rise of postmodernism in the last part of previous century, however, reminded us that science is not the ultimate, but only one of the apparatus to explore life.

Diffusion of scientism in $20^{\text {th }}$ century caused to examine the world with similar backgrounds among different schools of thought. Besides orthodox development economics, heterodox schools, e.g., institutionalism, dependency, Marxism, structuralism and historical schools generally utilized Newtonian tools. Eventhough some of them did not utilize them, they did not success in escaping from Newtonian worldview. This is because, modernism had effected 
every dimension of life.

If an approach share the same world view with counter approach that it criticizes, it is difficult to say that there exists a fundamental distinction between them. Models, scientific tools and results may be different, but the scientific reasoning itself is similar in orthodox and heterodox development theories. Frequently, the following properties are observed in both of them:

- constructing reality rather than explaining it,

- ideological assumptions rather than impartiality,

- bivalency rather than wholeness,

- competition rather than incorporation and interrelation,

- hierarchy rather than self-organizing and participation,

- growth centerism rather than multivalency,

- decomposing rather than preference,

- mechanical relations rather than organic ones,

- emphasizing on principles (one way of looking at reality) rather than multi dimension.

Because of the Newtonian perspective, the distinction between orthodoxy and heterodoxy is blurred. Newtonian assumptions prevent shedding new light on the concept of "economic development". Either of these seemingly competing thoughts presupposes that development is good for every society. They agree on context and content of development and on increasing the per capita values.

Orthodoxy advances some adequate measures to incorporate human and environmental issues to the inner structure of development on behalf of it and sometimes against heterodoxy. Heterodoxy is also deepening and renewing its older concepts and creating new ones at the same time. However, these efforts of heterodoxy do not directly and truly challenge Newtonian-based development economics. Instead, they are functioning as the efforts to call back or reanimate it. Only "projective belt" of development economics is charging, but its hard core is still remaining constant/unchanged. Quantum theory -with its fruitful content and its contextual, metaphorical and methodological implications- is the best candidate for transforming our existing worldview and, of course, development economics.

\section{Towards The Challenge}

What is the reason of emerging of "development economics"? This is not an easy question to answer. The question, however, can be changed as why did economists begin to interest in "development?" Historically development economics, as a matter of fact began with Adam Smith who was inquiring methods which would make England more wealthier. Smith was affected from 
natural philosophy and formulated economic development on liberalism freedom-productivity-labor axis (TEZEL, 1997). Although Smith and his followers dealt with economies in transition, they did not concern underdeveloped world. In colonial period, in fact, there was not clearly the term "underdeveloped". Among classical economists only Mill was interested in colonies, because of his job in East Indian Company (MILL, 1862: 324; HICKS, 1966: 260). In neoclassical era, the situation was worse as Marshall (1961: 737) confirmed that the interest in growth was too insufficient in neoclassical period (TEZEL, 1995: 15; HICK, 1966: 258).

The rise of development economics has two main well known causes. The first is the deconstruction of Second World War which soon acted as an improvement mission for Western Europe. Secondly, the colonies whom get their independence with worse economic conditions faced with development problem. Between the First and Second World Warship period, on the other hand, western economists studied on long-run economic problems and neglected LDC's. (BHAGWATI/ECKAUS: 1972, 16; also see MARSHALL, 1919: 161; PIGOU, 1924: 657; FISHER, 1915: 476). Only a limited number of studies investigated LDC's during the warship period. They can be grouped into three categories in this period. In the first one, western economists analyzed LDC's through the interests of their countries (see MITCHELL, 1942; BOWMAN, 1937). Second category was consisted of studies on depended (and semi-periphery) countries (see BOEKE, 1942; TRAEGER, 1963) and the last category was the researches of LDC's economists investigating themselves (see FONG, 1926; SEN, 1937).

\subsection{Unsuccessfulness : A Critique}

The limited studies of warship period might be evaluated as a result of the exploitative character of the relationship among developed countries. None of the metropolitan countries could manifest the negative effects of colonialism directly unless the periphery countries gained their independence. The conclusion was just the same. After Second World War, however, economists (also social scientists) of western world feel themselves free to analyze LDC's, because they were not colonies of their own countries anymore. Although neo-colonial period took place, economists began to investigate developmental issue lying on the breakdown of direct exploitative relationship.

Ironically, development studies were divided into left-right wings. The interesting point was that, this discussion was arising from Western world not from South. Many economists refrained from political restructuring processes that were taking place in LDC's. Thus, naturally focus of economists never directly concentrated on political and economic connections of development. 
Furthermore, development economists were unwilling to search undeveloped world against the dangers of acting as if intervening their internal politics.

Most of development economists were Europeans whom faced with the development problem. With the support of Keynesian thought, statism found a suitable platform to encourage its ideas. The result was the development plans and models. Besides all these efforts, an important point was missing. The third world was not matching with the orthodox assumption of "rational man". Western style solutions were not functional and operational in other regions. This missing point was easily solved by linearity assumption of mechanistic thought. Now or later, the third world would operate like the first world with
increasing per capita criteria!

Moreover, the problem of development was so important for LDC's. They did not have enough time to stop and think about philosophical or methodological aspects of western solutions. According to them, it was time to political dilemma. Thus the velocity of diffusion of "growthcenterism" from Europe to third world was so high. As a result, the cooperation of statism with growth centerism increased the practice of import-substitution where this cooperation also has a priority to the capital. Lending the foreign assistance accepted as one of the development instruments. Till "Oil Crisis" this mechanism has functioned well. Crisis, however, changed the direction, foreign assistance was blocked. This time, economies necessarily looked for an alternative which was sooner founded as a gift(!) from Western world -neo-liberalism. The contextual framework of neo-liberalism caused to decline of development economics, substituting it with again growth-centerism, but this time, with a
global view.

\subsection{Pseudo Transformation : The "New"}

In the last quarter of 1980's a "new" way to looking at growth initiated. Both new Keynesians and new classicals formulated the new growth theory. This theory over-emphasizes the role of human capital and technology in the aggregate production function in the long run for economic development. This theory, of course, unlike many of the other development economics theories, was originated from United States where the improvement of and emphasizing in information technology and related areas were relatively high. The theory proved itself (at least, at where it was initiated) by the peak performance of American economy in the last ten years. But, on the other side of coin, the new growth theory were still formulating development prospects from the stand point of linearity, that is, in order to increase income Western type solutions were imposed to undeveloped economies: "Do what I did". Moreover, this 
theory ignores the impeded economic development by shortcomings arising from imperfect capital and goods market, inadequate institutional structures, and poor infrastructure. In fact the applicability of these vital factors to the search for development in less developed economies is bounded with many limitations (ROMER, 1986; LUCAS, 1988, BARRO, 1990; PACK, 1994: 55-72; NAQVI, 1996: 977).

Following new growth theory, human capital, R\&D activities and infrastructure as complementary investments lost their relative importance against e-economy (new economy). Beginning from 1990's, besides these complementary investments, information technology began to be viewed as a "direct" new engine of growth. The rise of internet, and its application to economics, -cybernomics-, emerged a new focus area. This attempt was again initiated especially by Americans. But, several important questions should be addressed: "How unindustrialized world can benefit from new economy? If a country is technology consumer, can new economy develop in this country? Or can having huge amounts of investments on information technology without political freedom or stability be regarded as development? Or a more complex question can be asked: "can a pre-industrialized economy be transformed directly into a informative society?"

Shortly, transformation and evolving patterns, even structural change (the structural change toward informative society), are observed in the first world. The rhetoric of transformation, however, does not include a direct challenge to Newtonian thought. Although Torado (2000) argues that "Even more than other fields of economics, development economics has no universally accepted doctrine or paradigm", it is clear that Newtonianism is -still- serving as a constructive base for competing paradigms in development economics. The basic problem is that if we want to transform truly, we must firstly transform our thinking base.

\section{Transcending Boundaries}

Until now, with quick review of existing theories concerning economic development, we have tried to show the effect of mechanistic thought on development economics. Newtonianism, as a "meta-paradigm" or a "paradigm of paradigms", has been limiting our understanding on development economies with a great ignorance of the third world. So, are the Newtonian-based social science methods incapable of dealing with the complex and indeterminate problems which development economics is faced with today? Our answer is yes. It is the wedding of mechanistic logic and method to development economics theory and application that is problematic and it is the outdated models of scientific inquiry that slow progress. In fact, if the development economics want 
to do science as "hard science" does, it has to trace out the recent developments in physics_hard science. Because, mechanistic understandings in sciences depended upon Newtonian assumptions are challenged. The natural scientists are leaving out their Newtonian notions and replacing them with new ones since the turn of century. In the different fields of scientific inquiry emerging "new sciences" question great Newtonian machine image of human and universe, and reexamine the nature and the nature of people. Quantum theory, the leading field of new sciences, challenges not only directly to the physical sciences, but also to the social sciences -development economics- through changing their deterministic approaches.

The quantum theory offers valuable methods and metaphors that can challenge the development economics' study area in the new millenium. There is an agreement among increasing number of scholars and practitioners that economists (among also development economists) unnecessarily have used many social science research methods (natural science research methods) which long ago lost their ability to explain and predict the society (in the nature). Our analysis in this paper shows that through the lenses of Newtonian assumption development problem could not be solved, even could not be investigated
properly and sufficiently.

Shortly, the decline of Newtonian worldview in development economics arises from two main aspects. Firstly, Newtonian-based development economics views the development problem through the lenses of mechanistic images. By contrast, secondly, the object that development economics concerns is not mechanical in nature. Less developed countries and their transformation processes act like particles in the quantum world; they are not determinable and linear; they can create themselves in different forms as "dissipative" structures do. In order to understand this new way of looking, first of all we have to understand quantum world.

\subsection{The Basic Concepts and Philosophy of Quantum Theory}

Explaining quantum theory has always been difficult because it radically differs from traditional scientific theory and method. It offers a sharply new way to think about problems that we comfort and opportunities that we may have (ZOHAR, 1998) In essence, quantum theory specifies a physical world where electrons routinely jump from one orbit to the other and they spontaneously disappear from one reality and appear in the other, they do not exist separate from observer, that is, their existence and situations depend upon observer. Quantum mechanics partially takes the place of Newtonian "laws of motion" and "law of gravity" which have been effective in explaining reality in modern world. In quantum world there aren't any "dead particles" as in Newtonian 
sense. Capra (1983: 88) explains: "modern physics thus pictures matter not at all as passive and inert but as being in a continuous dancing and vibrating motion whose rhythmic patterns are determined by the molecular, atomic, and nuclear configurations. We have come to realize that there are no static structures in nature. There is stability, but this stability is one of dynamic balance..."

The Copenhangen interpretation of quantum theory, leaded by physicist Bohr and Heisenberg, initiated the stages of reformulating Newtonian physics into quantum physics (WHEELER/ZUREK, 1983). Unlike the linear world theorized by Newton where particles or matter are associated with concrete reality, there are invisible fields from relationships between particles in a quantum world and these fields are reality as much as physical matter is reality (WHEATLEY, 1992: 50). Moreover, this theory questions the classical concepts of solid objects and of strictly deterministic laws of nature. It proves that energy is not transferred or transformed (in an atomic scale) continuously but rather discontinuously in a indeterministic way. So, quantum theory is indeterministic, and it can be considered constructivist. This means that the only answers that are found are in the way we search for answers. In other words observer of an object is also necessary to define the properties of the object. Properties of any object have their meaning only through the their interaction with the observer. In quantum world, every attempt to observe changes the system and the object of observation (PEAT, 1987: 37). That's why quantum theories explained a universe not of certainty, but of indeterminism in which all we could ever know were the outcomes of our observations and not some fundamental truth or order. (The best example of this is Schrodingers's thought experiment of the cat in the box) (OVERMAN, 1996).

Some basic concepts of quantum theory (challenging Newtonian concepts) are given in Table 2.

Table 2: Basic Concepts of Quantum Theory

\begin{tabular}{|cc|}
\hline Indeterminism & Uncertainty \\
Improbability & Lack of objectivity \\
non-linearity & Complementarity \\
Particiaptorry collusion & Notion of "both" \\
Complexity & Disproportionalities between cause and effect chain \\
Fuzziness & Interrelatedness \\
Interconnection and interaction & Sensitivity to initial conditions (chaos theory) \\
Duality (wave-particle) & Holistism \\
Intersubjectivity & Context \\
Nonlocal causes & Potentiality \\
Indefinitiveness & Constructivism \\
Intentionality & Unknowability \\
\hline
\end{tabular}


As we mentioned before, quantum theorists do not describe the world as a world of certainty. Supported by experiment on the wave-particle duality of light, physicists have now uncovered what they believe to be reality of the quantum world. It is a world of complementarity and participatory collusion among particles in which "... two entities separated by many meters and processing no mechanism for communicating with each other nonetheless can be entangled: they can exhibit striking correlations in their behavior ..." (SHIMONY, 1986: 46). Thus, isolated material particles are abstractions, their properties can be defined and observed only through their interactions with other systems (HERBERT, 1985; CAPRA, 1983; PRIGOGINE/STENGERS, 1998). Quantum view, thus, describes physical (and, by implication socio-economic) systems in term of probabilities not probabilities of their individual parts or elements but of their interconnections.

The most important implications of quantum theory is Heisenberg's uncertainty principle, which implies that one can not know exactly all properties of a system. (KARSTEN, 1990: 385-386) For example, one can not determine the position and the momentum of a particle simultaneously, with great accuracy. In this world, if one of them is know precisely, the other will become uncertain (CAPRA, 1983: 158) So, the uncertainty principle limits the exact knowledge.

The apparent unpredictability might be due to hidden variables (POLKINGHORNE, 1984: 44) Moreover, knowledge can be ,erroneous and incompatible with existence. In Margane's (1984: 119) words. " ... its existence is knowable but questions whether it is actually known." That's why, true knowledge of an extend implies its existence, but existence does not necessarily imply true knowledge.

Neils Bohr interpreted the uncertainty principle as complementarity. According to this interpretation, the scientist (also economist) can no longer be evaluated as an impartial observer but as an active participator (PEAT, 1987: 37) Quantum theory includes the human observer or consciousness in its description of the nature. Furthermore, the tools or perspectives of human observer changes the course of the objects' behavior and hence, one cannot specify objectively the state of the object. It is possible to say that as the science develops, it does more than merely investigation, it also creates new ones at the same time.

To summarize, quantum theory can be identified by four principles which distinguish it from Newtonian world view:

1. Uncertainly in that one can measure the position or velocity of an particle (electron), but not both simultaneously.

2. Improbability in that one can estimate the likelihood of a given outcome, but one can not say what will actually occur next. 
3. Interactive and interconnected in that one cannot divide a system into discrete parts in order to understand now the whole system works because the relationship are as important as the parts.

4. The lack of objective reality in that the act of measurement changes what will be observed. That is, constructivism.

\subsection{Quantum Economic Development}

Depending on our explanations, quantum economic development is a perspective with different facts on energy not matter, on becoming not being, on coincidence not causes, on constructivism not determinism, and on new states of awareness and consciousness. In quantum economic development, expectations of objective reality, certainty, and simple causality are meaningless. That's why, it differs from traditional economic development approaches.

Development economist view the economic and political systems of LDC's as what chaos theorists would call "far from equilibrium". That's why, they try to linearize this unequilibrium state by simply offering pre-determined models into the system. This ignores the self-organizing and self-developing capacities of LDCs. These countries, seeming out of control and complex, may have capacity to redefine development. For example, after the rise of Southeast Asia countries, development economists began to formulate models for other LDC's depending on the miracle factors of Southeast Asia economies. But, interestingly, these economists also showed the erroneous of miracle making countries after the crisis. In fact, this was a result of determinism which presumes that every similar actions will cause similar reactions. However, similar actions of different countries with different socio-economic endowment will not necessarily cause same results. Quantum economic development implies that every object (LDC's) has unique features which can not be substituted by some other models. Classifying countries may be useful in some manner, but on the other hand, this neglects many other facts. Because, with the interaction of outside forces, every less developed country, depending on collective and participatory behaviors of quantum reality, potentially constructs its own development paradigm. Furthermore, classifying countries, -performance evaluation-, is designed to provide an objective measure of an economy's improvements or shortcomings. But according to quantum economic development perspective, economic performance cannot be broken down to questions or assignments and scores, and what is judged good or bad often can be complementary. Explicitly performance is relative and intersubjective, and more importantly, any attempt to measure performance changes the performance. The causes of economic performance are widely dispersed across social, political and cultural worlds with no singular cause and multiple 
possibilities for "nonlocal causation". Also the relationship between performance and development is not only conjugated, but dynamic as well. The assumption underlying the uncertainty principle was that any measurement on a system will spontaneously changes the properties of the other. That is, any measurement of performance will change development and vice versa, in either direction.

Developing countries have similar characteristics with quantum world, rather than Newtonian world. Because;

1. They act in a dynamic and chaotic environment

2. Besides economic factors, myriad factors effect them

3. They are observed from outside, so there is lack of impartiality and objectivity

4. Gathering exact and true information about socio-economic factors are generally impossible

5. They have creative and constructive structures

6. They act in an unstable and ever-changing environment

7. They are not homogenous, or do not show similar characteristics

But the main perspective argued in this paper is not to find out or stress the similarities between quantum and undeveloped world, instead, but rather need to change of our scientific reasoning which in turn lead a change in development economics.

The wholeness or holistic approach of quantum economic development may cause to reinterpret the relationship between man and nature. Until now, sustainable development has been regarded the continuancy of economic development. But quantum economic development implies the wholeness of economic development. For a long time, the role and the function of natural environment had been ignored in theoretical studies of economies (KARSTEN, 1987). It is impossible to see environmental issues in the studies of classical economists, like Smith and Ricardo, as in the case of Hobbes or Bacon. The nature was regarded as a free good, or in general, economists assumed an infinitely available and infinitely self-generating nature. Quantum theory may limit the exploitation of nature or it may show the costs of exploitation of nature to the society. In other words, it reminds us people are the part of nature with responsibility to project it (RIFKIN, 1980). So, "unless we understand the subtitles of wholeness, we will not divide what can not be divided, will try to unite what can not be united" (BRIGGS/PEAT, 1984)

The quantum economic development is connected with social, political and ethical issues, as an organic whole. That's why, the reductionism of traditional economic development is insufficient to explore development process. The ceteris paribus of orthodox economics divides the economic 
universe into definitive segments, this, in turn limits our understanding of them.

The basic properties of quantum economic development is as follow :

- Living systems have priority (not a position as in Newtonian hierarchy). They have more meaning and importance than numerical values or indicators. Machines have no innate desires, motivations, or intelligence. (WHEATLEY and KELLNERROGERS, 1996: 11) Everything must be built into them imposed from the outside. However, LDC's have commitment, motivation, and quality as living systems. They can change when necessary, but they are adapt by tinkering. LDC's tinker in their environments, exploring new possibilities, new forms of creative self-development. That is, in tinkering, they do with what is at hand: a solution does not have to be right, it just has to work.

- Quantum economic development relies less on precise planning. Precise planning may not be beneficial where too many minor variables can change, altering a precise plan. (STILLWELL, 1996: 7) In other words, quantum economic development concentrates on the informal processes and relationships in meeting goals, rather focusing on exact values in development theories and models.

- Quantum economic development initiates "self-development". This means that we have ability to learn, adapt and create where our ability is fed by information. We maintain an acute awareness of what is occurring around us. So quantum economic development depends on responsiveness. It is important to be aware of emerging fluctuations and to adapt to them. In order to do this quantum economic development must be adaptive and flexible. That's why, it avoids longer-term forecasts and instead relies on shorter-term views.

- A quantum economic development must be green. Because quantum universe is a participatory universe. The observer is a part of the observed phenomena. Quantum economic development should concern social, cultural and natural environment both externally and internally (ZOHAR, 1998: 58) Quantum ecology interests itself in the earth as a total system, a system with a human, meaning-centered dimension that is in symbiosis with its non-human but life-centered dimension.

- In quantum economic development people as parts of living systems have self-creating capacities like other forms of life. They do not require outside engineering or detailed design. Quantum economic development is unfolding. It is about "potentiality" more than "actuality", about the "what might be" rather than the "what is". It is learning process rather results-oriented economic development, it recognize the value of taking risks.

- Quantum economic development emphasizes on relations, relations between economic, social, political and cultural variables. In quantum world, 
socio-economic systems are one indivisible and dynamic. Whole parts are interrelated in very fundamental ways. This, in turn, avoids economic analysis and connects economic and social variables. In quantum world, it is connections or relationships between things that count, not things themselves, because each thing drives its meaning from relationship it has with other things, rather than from fundamental local properties it has. (MCDANIEL/WALLS, 1997: 370) Shortly, the whole organizes the parts and every part is related to and partially defined though every other part.

- Quantum theory leads us the conclusion that the future studies of a socio-economic system is unknowable. If the future is unknowable, then quantum economic development comes through learning rather than knowing. This learning is a real time learning arises from unfoldings and interactions between environmental factors. Thus, the unpredictability of the world makes learning in preparation for action less useful than learning as we act (WALL, 1996).

- Quantum economic development is not about black or white, it is about gray. This challenges traditional economic development because it makes harder to quantify. If quantification gets harder, also precise modeling and fine-tuning the economy gets harder. That's why quantum economic development favors "experimentalism" as opposed to "deductivism" (MORCOL, 1996: 320). Using mathematics or statistics in development studies does not make them inherently more or less scientific or objective. Then quantum development economists might infuse qualitative understanding into their mainly quantitative body of knowledge.

Traditional development economics, like an outside observer, ignored "contextualization" and accepted "nonlinear dynamics" as more randomness or noise. In fact, there may be more information contained in the noise than what has been listened to previously. Dualism, structural limitations, diversity, poor infrastructure and many other variables can evolve to any direction which will lead to higher satisfaction according to quantum economic development. This evolution is not pre-determined Newtonian evolution, instead it is dynamic, unpredictable, and unfolding. "A small change in initial condition may cause greater effects" implies that LDC's can be seen similar, in fact, they potentially have greater differences. Newtonian linearity had prevented development economies to understand power of non-linearity.

In quantum economic development, each country assumed to be unique. This uniqueness does not only come from internal factors, but also with the web of connections from outside. A key feature of the unstable web of connection for economic development is performance improvement, which is facilitated by reliance on process rather than economic structure and economic goals. Contrary to the traditional vision of economic development stresses the 
importance of economic structure and goals, there is a clear need to see socio-economic systems as "infinitiveness of processes". Then, the main tasks of development economists might be as follows : to express the process of self-development in dynamic socio-economic systems; to identify the characteristics and components of self-development; to define the conditions that facilitate self-development; to present "case specific information".

Consequently, quantum economic development questions the mechanical ways to approach to the development problem. In fact, it also challenges the "problem", because the problems that we identify might not be problem in quantum world, instead, they might be instruments to realize development.

\section{Conclusion}

Discussion on adjusting the field of development economics to encompass quantum theory is new and its applications to developmental issues are get uniquely metaphorical and wholly imaginary. Quantum theory is still at a high level of abstraction and offers little in the way of contribution for current development practices. It, however, offers acceptable paradoxes and criticisms of traditional scientific understanding, and it offers tangible solutions aside from the motion of raising our awareness of the universe around us that is constructed by a web of connections.

Quantum theory is a new subject for social scientists, even for economics. Therefore, there are only a few number of papers in economics concerning quantum theory. It can be said that quantum theory is in a "post-embryonic" state in social sciences, including economics. But, it has significant methodological and metaphorical aspects and more meaning than a "pop-science". The use of metaphor is the first stage for quantum economic development. It would not be easy for traditionalist who get used to study in Newtonian sense. He or she will need a radical re-examination of the logic of current development issues.

Quantum theory has potentially so many implications for all fields of social sciences. Development economies, again potentially, assumed to be a candidate for the implication of quantum understanding in this study. Because, as it was mentioned before, it gets used to work with alternative paradigms. This means that a relative holistism and relativism which can not be seen in any other fields of economics. 


\section{References}

ADELMAN, I. / MORRIS, C.T. (1967), Society, Politics and Economic Development (Baltimore: John Hopkins University Press).

ADELMAN, I. / MORRIS, C.T. (1988), Comparative Patlerns of Economic Development, 18501914 (Baltimore: John Hopkins (nniversity Press).

BARRO, Robert (1990), "Government Spending in a Simple Model of Endogenous Growth," Journal Political Economy, 98.

BHAGWATI, Jagdish / ECKAUS, R.S. (1972), Development and Planning (London: George Allen and Unwin Ltd.).

BOEKE. J.H. (1942). The Structure of Netherlands, Indian Economy (Institute of Pacific Relation).

BOWMAN, I. (1937), Limits of Land Settlement (Council on Foreign Relations)

BRIGGS, John / PEAT, David (1984), Looking Glass Universe (New York: Simon and Schuster).

CAPRA, Fritjof (1983), The Tuming Poinl (London: Flamingo).

CARLSON, Mathiew J. (1997), "Mirowski Thesis and The Integrability Problem in Neoclassical Economics," Journal of Economic lssues, 31.

CHENERY H. / SYRQUIN M. (1975), Patterns of Development, 1950-1970 (New York: Published for the WB by OUP).

CAKIR, Necip (1998). Physics and Economics (Ankara: Sermaye Piyasası Kunulu Yayınları).

DULUPCU, Murat (1999), "lktisadi Paradigmatik Dönüşüm: Kozmolojik Iktisattan Kaotik ve Kuantum Iktisadına Geçiş," Iktisat Dergisi, 389.

DULUPCU, Murat / OKÇ U, Murat (2000), "Chaos and Quantum Theories Possibilities and Applications For Economics and Management Sciences," Irwited Paper for International Management Sciences Congress, 10-13 May (lstanbul: ITÜ).

FISHER, Irving (1915), Elementary Principles of Economics (London:Macmillan).

FONG, H.D. (1936), Towards Economic Conlrol China (China Institute of Pacific Relations).

HERBERT, N. (1985), Quantum Reality : Beyond the New Physics (New York: Doubleday).

HICKS, J.R. (1966), "Growth and Anti-Growth," Oxford Economic Papers (November).

HIRSCHMAN, A. (1981). "The Rise and decline of Development Economics," Essays in Trespassing: Economics, Politics and Beyond (Cambridge: Cambridge (nniversity Press).

HODGSON, Geoffrey M. (1993), Economics and Evolution : Bringing Back Life Into Economics (Oxford: Polity Press).

INGHAM, Barbara (1995), Economics and Development (Cambridge: McGraw-Hill).

KARSTEN, Siegfired (1990), "Quantum Theory and Soclal Economics: The Holistic Approach of Modern Physics Serves Better Than Newton's Mechanics in Approaching Reality," American Journal of Economics and Sociology, 49.

KARSTEN, Siegfried (1987). "Nature in Economic Theories: The Investigations of Hans Immler," American Journal of Economics and Sociology, 46.

KUZNETS, S. (1973), "Modern Economic Growth: Findings and Reflections," American Economic Review, 63.

LOASBY. Brain (1991), Equilibrium and Evolution: An Exploration of Connecting Principles in Economics, (Manchester: Manchester University Press). 
LUCAS, Robert (1988), "On The Mechanics of Economic Development," Journal of Monetary Economics, 22 : 3-42.

MARGENAU, Henry (1984), The Miracle of Existence (Woodbridge: Oxford Press).

MARSHALL, A. (1919), Industry and Trade (London: Macmillan).

MARSHALL, A. (1961), Principles of Economics (London: Macmillan, $9^{\text {th }} \mathrm{ed}$.).

MCDANIEL, Reuben R. / WALLS, Michelle E. (1997), "Diversity As a Management Strategy For Organizations: A Vlew Through the Lenses of Chaos and Quantum Theories," Joumal of Management Inquiry, 6.

MILL, J.S. (1862), Principles of Political Economy Vol. 2 (London, $5^{\text {th }}$ ed.).

MIROWSK1, Philip (1988), Against Mechanism : Protecling Economics From Science (Lenham: Rowman and Littlefield).

MIROWSKI, Philip (1989), More Heat Than Light-Economics as Social Physics: Physics as Nature's Economics (Cambridge: Cambridge University Press).

MIROWSKI, Philip (1993), "The Goalkeeper's Anxiety at the Penalty Kick," DE MARCHI. N. (ed.) Non-Natural Social Science (Durham, N.C.:Duke University Press).

MITCHELL, Kate C. (1942), Industrialization of the Western Pacific (Institute of Pacific Relations).

MORCOL, Goktug (1996), "Fuzz and Chaos : Implications for Public Administration Theory and Research," Joumal of Public Administration Research and Theory, 6.

NAQVI, S.N.H. (1996), "The Significance of Development Economics." World Development, 24.

NELSON. Richard (1995), "Recent Evolutionary Theorizing About Economic Change," Journal of Economic Change, 33.

NELSON, Richard / WRITER, Sidney (1982), An Evolutionary Theory of Economic Change (Cambridge: Harvard University Press).

OVERMAN, Sam (1996), "The New Science of Management: Chaos and Quantum Theory and Method," Joumal of Public Administration Research and Theory, 6.

PACK, Howard (1994), "Endogenous Growth Theory: Intellectual Appeal and Empirical Shortcomings," Joumal of Economic Perspectives, 8: 55-72.

PEAT, David (1987), Synchronicity (New York: Pantam Books).

PIGOU, A.C. (1924), The Economics of Welfare (London: Macmillan, $2^{\text {nd }}$ ed.).

POLKING Horne, J.C. (1984), The Quantum World (London: Longman).

PRIGOGINE, llya / STENGERS, Isabella (1998), Kaoslan Düzene (Istanbul: Iz Yayıncilık) (Cev. Senai Demirci).

RANIS, G. (1984), "Typology in Development Theory : Retrospective and Prospects," SYRQUIN, M. et. al (eds), Economic Structure and Performance (London: Academic Press).

RIFKIN, Jeremy (1980), Entropy (New York: Viking Press).

ROBINSON, Joan (1979), "History versus Equilibrium," Collected Economic Papers, 5, (Oxford: Oxford University Press).

ROMER, Paul (1986), "Increasing Retums and Long-run Growth," Journal of Political Economy. 94: $1002 \cdot 1037$.

ROSTOW, W.W. (1956), The Stages of Economic Growth (Cambridge: Cambridge University Press).

SEN, K.N. (1937), Economic Reconstruction of India: A Study of Economic Planning (Calcutta: University of Calcutta). 
Murat Ali Dulupçu - Murat Okçu • Towards Quantum Economic Development: Transcending Boundaries • $5 \mathbf{3}$

SHIMANY, A. (1986). "The Reality of Quantum World," Scientific American, 258.

STILWELL, J. (1996), "Managing Chaos : Use it to Your Advantage," Public Management, 78.

STREET, J.H. / JAMES, D.D. (1982), "Intstituonalism, Structuralism and Dependency," Joumal of Economic Issue, 16/3: 673-689.

SYRQUIN. M. (1998) "Patterns of Structural Change," CHENERY, Hollins / SRINIVOSAN, T.M. (eds.) Handbook of Development Economics Vol. I (North Holland: Elsevier).

TEZEL, Y.S. (1995), Iktisadi Büyüme (Ankara).

TEZEL, Y.S. (1997), Iktisadi Büyüme (Ankara).

TORADO, Micheal (2000), Economic Developmenl (Massachusetts: Addison-Wesley, $7^{\text {th }}$ ed.).

TRAEGER, F.N. (1963), Survivals of Burma (Yale University Press).

WALL, E.B. (1996), Learning as a Way of Being: Strategies for Survival in a World of Permanent Whitewater (San Francisco: Jossey-Bass).

WHEATLEY, M.J. / KELLNER-ROGERS, M. (1996), "Breathing Life into Organizations: A New World View Based on Chaos and Complexity," Public Management, 78.

WHEATLEY, Margeret (1992), Leadership and The New Sciences: Learning About Organization From Orderly Universe (San Francisco: Barrett-Koehler).

WHEELER, John A. / ZUREK, W.H. (1983), Quantum Theory and Measurement (Princeton: Princeton University Press).

WITT Ulrich (eds.) (1992), Explaining Process and Change : Approaches to Evolutionany Economics (Ann Anbar: University of Michigan Press).

ZOHAR, Danah (1998), "What Would A Quantum Organization Look Like?," Management Revieu, 87.

ZOHAR, Danah (1998b), Kuantum Benlik (Istanbul: Sarmal Yayınevi) (Cev. Seda Kervanoğlu). 